\title{
STRATEGI PEMBELAJARAN AKTIF UNTUK PENINGKATAN EFEKTIVITAS PEMBELAJARAN TRIGONOMETRI
}

\author{
Anik Setyowati \\ SMA Negeri 1 Wedi Klaten, \\ anikendar10@gmail.com
}

\begin{abstract}
Abstrak
Penelitian ini bertujuan untuk mencari suatu strategi pembelajaran yang efektif dan efisien dalam mengajarkan materi trigonometri bagi siswa kelas $\mathrm{X}$ MIPA 1 di SMA Negeri 1 Wedi dengan cara mengaktifkan siswa pada pembelajaran. Penelitian tindakan kelas ini dilakukan dalam 2 siklus dan pada setiap siklus meliputi kegiatan perencanaan, pelaksanaan, observasi dan refleksi. Sedangkan untuk mengaktifkan siswa dalam penelitian ini, peneliti menggunakan lembar kerja yang diberikan kepada siswa dalam kelompok besar dan kelompok kecil. Subjek pada penelitian ini adalah siswa kelas X MIPA 1 SMA Negeri 1 Wedi, sedangkan objeknya adalah pembelajaran materi trigonometri pada mata pelajaran matematika yang diajarkan dengan cara mengaktifkan siswa dalam kelompok kecil dan kelompok besar. Penelitian yang diadakan dengan meneliti kondisi awal siswa yang diukur melalui alat tes tertulis dan hasil penelitian tindakan kelas dengan 2 siklus terlihat adanya peningkatan hasil yang dicapai siswa dalam menguasai materi trigonometri yang diberikan. Adapun hasil penelitian menunjukkan bahwa pembelajaran materi trigonometri dalam kelompok kecil dengan cara mengaktifkan siswa dapat meningkatkan penguasaan materi dari 71,43\% pada siklus I menjadi 89,29\% di siklus II. Berdasarkan hasil penelitian ini direkomendasikan untuk mengajarkan materi trigonometri dalam pembelajaran kelompok kecil dengan teknik mengaktifkan siswa dengan tanya jawab dan diskusi karena strategi pembelajaran aktif dapat meningkatkan efektivitas pembelajaran trigonometri.
\end{abstract}

Keyword: Strategi Pembelajaran, Pembelajaran Aktif, Efektivitas, Trigonometri.

\section{PENDAHULUAN}

Pada setiap pengajaran terdapat tujuan yang harus dicapai dan pencapaian tujuan tersebut perlu disampaikan topik - topik yang ada didalamnya. Konsep konsep yang harus disampaikan kepada siswa diperlukan pendekatan atau strategi pemecahan masalah, latihan soal, latih - hafal dan pendekatan yang lainnya. Nasution (1982: 243) menyatakan bahwa dalam suatu pengajaran yang berkaitan 
dengan suatu materi kurikulum tertentu prinsip keterlaksanaan dipenggaruhi oleh empat komponen pokok yaitu pembawa materi, penyaji materi, pendekatan dan penerima materi. Pengaturan materi kurikulum tersebut dinamakan strategi belajar mengajar.

Matematika banyak yang menganggap sebagai pelajaran yang sulit sehingga pelaksanaan pengajaran perlu dilakukan adanya penelitian supaya didapatkan pengajaran yang paling efektif untuk digunakan, baik dalam kesempatan yang sekarang maupun yang akan datang. Pembelajaran efektif diperlukan strategi pembelajaran aktif. Pembelajaran aktif yang mampu mengaktifkan siswa didalam kelas sehingga siswa mampu berpikir secara kritis. pembelajaran aktif menurut Zaini, Munthe \& Aryani (2007: xvi) adalah suatu pembelajaran yang mengajak peserta didik untuk belajar secara aktif. Ketika peserta didik belajar dengan aktif, berarti mereka yang mendominasi aktifitas pembelajaran.

Menurut Muijs \& Reynolds (2008: 65 - 66) Suatu pengajaran klasikal agar efektif maka harus jauh dari sekedar menyampaikan isi pelajaran dengan gaya ceramah kepada murid. Tanya jawab dapat digunakan untuk memeriksa pemahaman siswa untuk memberikan dasar pada pembelajaran siswa, untuk membantu siswa dalam mengklarifikasikan dan memverbalisasikan pikiran mereka, dan membantu siswa mengembangkan sense of mastery (perasaan menguasai sesuatu). Tanya jawab yang efektif dapat terjadi bila penguasaan diri yang solid tentang strategi - strategi mana yang paling efektif.

Bentuk interaksi lain yang efektif dalam pembelajaran adalah diskusi kelas, namun suatu diskusi supaya efektif perlu dipersiapkan dengan seksama. Pengajar perlu memberikan pedoman yang jelas kepada siswa tentang hal yang didiskusikan. Selama diskusi siswa perlu dipastikan untuk tetap pada tugasnya, dan guru perlu menuliskan poin - poin utama yang muncul selama diskusi. Setelah diskusi poin-poin utama (produk diskusi) ini dapat dirangkum dan siswa diminta untuk meberikan komentar tentang seberapa baik diskusi itu tersebut berjalan (proses diskusi). 
Pembelajaran aktif merupakan suatu bentuk pembelajaran yang lebih banyak melibatkan aktivitas siswa dalam mengakses berbagai informasi dan pengetahuan untuk dibahas dan dikaji dalam proses pembelajaran di kelas, sehingga mereka mendapatkan berbagai pengalaman yang dapat meningkatkan pemahaman dan kompetensinya. Lebih dari itu, pembelajaran aktif diharapkan siswa mampu mengembangkan kemampuan berfikir tingkat tinggi, seperti menganalisis dan mensintesis, serta melakukan penilaian terhadap berbagai peristiwa belajar dan menerapkan kehidupan sehari-hari (Rusman, 2011). Di sisi lain, Zaini mengatakan pembelajaran aktif adalah pembelajaran yang mengajak siswa untuk belajar serta aktif. Ketika siswa belajar dengan aktif, berarti mereka yang mendominasi aktifitas pembelajaran. Secara aktif mereka menggunakan otak, baik untuk menemukan ide pokok dari materi pelajaran, memecahkan persoalan, atau mengaplikasikan hal yang baru mereka pelajari ke dalam satu persoalan yang ada dalam kehidupan nyata. Belajar aktif ini, siswa diajak untuk turut serta dalam semua proses pembelajaran, tidak hanya mental akan tetapi juga melibatkan fisik. Cara pembelajaran ini siswa akan merasakan suasana yang lebih menyenangkan sehingga hasil belajar dapat dimaksimalkan (Zaini, 2008).

Kadar belajar siswa aktif dapat dilihat dari ciri-ciri yaitu,

1. Adanya keterlibatan siswa secara fisik, mental, emosional, intelektual, dan personal dalam proses belajar,

2. Adanya berbagai keaktifan siswa mengenal, memahami, menganalisis, berbuat, memutuskan, dan berbagai kegiatan belajar lainnya yang mengandung unsure kemandirian yang cukup tinggi,

3. Keterlibatan secara aktif oleh siswa dalam menciptakan suasana belajar yang serasi, selaras dan seimbang dalam proses belajar dan pembelajaran,

4. Keterlibatan siswa dalam mengajukan prakarsa, memberikan jawaban atas pertanyaan guru, mengajukan pertanyaan/masalah dan berupaya menjawabnya sendiri, menilai jawaban dari rekannya, dan memecahkan masalah yang timbul selama berlangsungnya proses belajar mengajar tersebut (Hamalik, 2003). 
Sementara itu Sudjana (1995: 22) mengemukakan bahwa hasil belajar matematika adalah kemampuan-kemampuan yang dimiliki siswa setelah ia memperoleh pengalaman belajarnya. Gagne \& Briggs (1977: 47-48) mengelompokkan hasil belajar menjadi lima bagian dalam bentuk kapabilitas yakni ketrampilan intelektual strategi kognitif, informasi verbal, ketrampilan motorik dan sikap.

Pada kesempatan ini peneliti mengadakan penelitian tentang rendahnya penguasaan siswa pada materi trigonometri, dan yang menjadi fokus pada penelitian ini adalah tidak efektifnya pengajaran yang dilakukan oleh guru dalam mengajarkan materi trigonometri tersebut. Tidak efektifnya pengajaran yang dilakukan guru tersebut diduga akibat kurang tepatnya guru dalam menggunakan strategi pembelajaran. Hal ini ditandai adanya kecenderungan guru dalam mengajarkan materi tersebut dengan metode ceramah secara klasikal.

Peningkatan hasil belajar pada materi trigonometri dan efetifitas pembelajaran yang diharapkan oleh peneliti adalah dengan langkah mengarahkan pembelajaran siswa aktif secara kelompok besar maupun dalam kelompok kecil. Selain itu juga penelitian ini diharapkan dapat merubah paradigma guru dalam melakukan pembelajaran dari guru sebagai pusat belajar supaya beralih ke siswa. Hal ini berguna untuk mewujudkan harapan yang diinginkan oleh peneliti dalam menerapkan strategi pembelajaran aktif dengan menggunakan teknik pembelajaran kelompok besar dan pembelajaran kelompok kecil.

Penerapan strategi pembelajaran yang dilakukan di kelas memiliki tujuan untuk meningkatkan penguasaan materi Trigonometri bagi siswa kelas X MIPA 1, mencari pengajaran yang efektif untuk mengajarkan materi trigonometri bagi siswa kelas X MIPA 1 selain itu meningkatkan penguasaan materi trigonometri bagi siwa kelas X MIPA 1 di SMA negeri 1 Wedi tahun pelajaran 2018 - 2019 dengan menggunakan strategi pembelajaran aktif.

\section{METODE}

Penelitian ini dilaksanakan dengan mengambil lokasi di SMA Negeri 1 Wedi , Kota Klaten dengan pertimbangan: (a) SMA Negeri 1 Wedi termasuk sekolah 
pingiran sehingga perlu adanya penelitian tentang pendekatan pembelajaran yang paling efektif supaya prestasi matematika siswa - siswa sesuai dengan harapan. (b) kemudahan dalam pelaksanaan penelitian karena peneliti merupakan staf pengajar di SMA Negeri 1 Wedi. (c) Adanya ikatan batin yang baik antara peneliti dengan seluruh warga sekolah.

Penelitian tindakan kelas ini dilaksanakan dari bulan Februari tahun 2019 sampai dengan bulan April tahun 2019, menggunakan jenis perlakuan tindakan kelas (class room action research) dengan menggunakan 2 siklus. Subyek dari penelitian tindakan kelas ini adalah siswa kelas X MIPA 1 SMA Negeri 1 Wedi tahun ajaran 2018 - 2019. Pengambilan subjek penelitian ini didasarkan pada kondisi kelas yang mampu mewakili siswa kelas X secara keseluruhan. Dalam penelitian tindakan kelas ini pengumpulan data menggunakan berbagai teknik antara lain :

1. Tes Tertulis

Tes tertulis disini digunakan untuk mengumpulkan data siswa berkenaan hasil pengusaan materi trigonometri yang dikuasai siswa, setelah siswa mengikuti suatu proses perlakuan yang dilakukan oleh peneliti, sehingga didapatkan hasil yang akurat dan dapat menggambarkan secara jelas kemampuan siswa dalam menguasai materi trigonometri tersebut.

2. Alat Pengumpul Data.

Untuk mengetahui kemampuan yang dikuasai siswa dalam penguasaan materi yang dijadikan obejek penelitian ini, peneliti menggunakan alat yang berupa tes tertulis yang telah dirancang oleh peneliti sesuai dengan tujuan yang telah tertuang didalam kisi - kisi soal .

3. Deskripsi perilaku ekologis

Pada teknik ini peneliti mencatat observasi dan pemahaman urutan perilaku siswa dengan lengkap meliputi :

a. suasana kelas

b. perilaku masing - masing siswa saat mengikuti pembelajaran di dalam kelas 
pada penggunaan metode ini peneliti hanya untuk mengumpulkan data dan bukan untuk menafsirkan data.

Sebelum mengadakan tindakan pada penelitian ini, maka peneliti mengadakan observasi cara mengajar guru dalam kelas serta mencari data kemampuan awal penguasaan materi trigonometri dari siswa. Seperti telah dijelaskan sebelumnya bahwasannya pada penelitian tindakan kelas ini dilakukan dalam 2 siklus namun bila dari dari dua siklus yang direncanakan masih terdapat masalah yang harus dipecahkan maka dapat dilanjutkan dengan siklus berikutnya. Pelaksanaan prosedur penelitian yang dilakukan oleh peneliti sebagai berikut :

\section{Diskripsi siklus I.}

a. Tahap perencanaan tindakan.

Dalam tahap perencanaan tindakan pada siklus ini, kegiatan yang dilakukan adalah:

1) Peneliti menyusun silabus yang berkaitan dengan materi trigonometri.

2) Peneliti merancang skenario pembelajaran yang dapat mengaktifkan secara kelompok besar.

3) Merancang alat pengumpul data yang berupa tes dan digunakan untuk mengetahui pemahaman kemampuan siswa yang berkaitan dengan materi trigonometri.

b. Tahap pelaksanaan tindakan.

1) Pada siswa diberikan penjelasan umum tentang tujuan penelitian tindakan kelas sesuai dengan rancangan yang telah direncanakan, baik mengenahi pengumpulan data maupun kegiatan -kegiatan yang lain.

Kegiatan dalam penelitian tindakan kelas ini meliputi : (a) Memberikan penjelasan secara umum tentang pokok bahasan yang diajarkan dengan mengunakan strategi pembelajaran aktif dengan tehnik menstimulir rasa ingin tahu siswa (b) Mendorong siswa yang belum aktif untuk aktif dalam mengikuti pembelajaran. (c) 
Mengamati dan mencatata siswa yang berpartisipasi aktif dalam pembelajaran (d) Mengumpulkan hasil pengujian yang diperoleh siswa dalam mengerjakan tugas (e) Menganalisa hasil tes yang diberikan setelah siswa diajar dengan tehnik menstimulir secara kelompok besar.

2) Peneliti mengajar sesuai dengan skenario pembelajaran klasikal yang telah dirancang dan mencatat kegiatan - kegiatan yang dilakukan oleh masing - masing siswa.

3) Peneliti memberikan evaluasi pada siswa untuk mengetahui pemahaman siswa berkaitan dengan materi Trigonometri.

c. Tahap observasi tindakan.

Peneliti mengamati dan mencatat semua kejadian yang terjadi pada saat siswa mengikuti pengajaran dan menanyakan pada siswa yang kurang aktif dalam pembelajaran tentang kesulitan-kesulitan yang dihadapinya.

d. Tahap refleksi.

Peneliti menganalisa hasil pekerjaan siswa dan hasil observasi yang dilakukan pada siswa guna menentukan langkah berikutnya.

Peneliti membuat pengelompokkan siswa didasarkan pada hasil yang didapatkan siswa pada evaluasi yang dilakukan.

\section{Diskripsi siklus II.}

a. Tahap perencanaan tindakan.

1) Mempersiapkan fasilitas dan sarana yaitu dengan membuat kelompok siswa dengan penyebaran siswa yang menguasai materi awal yaitu materi yang telah disampaikan pada siklus I .

2) Membuat pengurus pada masing - masing kelompok mencakup fasilitator, pencatat, juru bicara dan pengatur waktu.

3) Membuat bahan ajar yang akan disampaikan pada masing - masing kelompok.untuk didiskusikan

b. Tahap pelaksanaan tindakan. 
1) Peneliti memberikan penjelasan tentang pokok bahasan trigonometri yang akan dipelajari serta menjelaskan kegiatan yang akan dilaksanakan berkaitan dengan pengajaran dalam tehnik menstimulir siswa untuk belajar bersama dalam kelompok.

2) Siswa yang telah menguasai pada materi awal di siklus I dimohonkan memimpin pembahasan bahan ajar yang diberikan peneliti. Bahan ajar yang diberikan berisi tugas memecahkan masalah tindak lanjut dari siklus I.

3) Memberi kesempatan pada masing - masing kelompok untuk menyajikan hasil diskusi

4) Pembahasan materi ajar yang siswa dalam satu kelas mengalami kesulitan ataupun salah dalam apersepsinya

5) Memberikan evaluasi pada siswa untuk mengetahui kemampuan siswa dalam menguasai pengerjaan soal penerapan trigonometri.

c. Tahap observasi tindakan.

1) Peneliti mencatat hasil-hasil yang diperoleh siswa serta mencatat kesalahan - kesalahan yang dilakukan siswa dalam mengerjakan masalah yang berkaitan dengan bahan ajar yang diberikan.

2) Peneliti mencatat kesalahan - kesalahan yang dilakukan siswa dalam menyelesaikan masalah pada bahan ajar yang diberikan..

d. Tahap refleksi.

Peneliti membuat inventarisasi kesulitan yang dilakukan siswa dalam menyelesaikan masalah pada bahan ajar yang diberikan serta mendata siswa yang telah mampu menyelesaikan soal evaluasi dan mampu mendapatkan nilai diatas standart ketuntasan belajar.

\section{HASIL PENELITIAN DAN PEMBAHASAN}

Sebelum penelitian tindakan kelas ini dilaksanakan, peneliti mengadakan observasi dan pengumpulan data dari kondisi awal kelas yang akan diberi tindakan, yaitu kelas X MIPA 1 SMA Negeri 1 Wedi, tahun pelajaran 2018 2019. Berdasarkan observasi yang dilakukan oleh peneliti didapatkan bahwa pada 
pengajaran yang dilakukan, guru masih menggunakan cara pengajaran yang tradisional yaitu guru sebagai pusat pembelajaran dan pengajaran materi dalil phytagoras dan perbandingan trigonometri pada segitiga siku - siku tersebut diajarkan dengan menggunakan metode ceramah. Pada pembelajaran berlangsung terlihat siswa asyik dengan kegiatannya sendiri yang tidak ada kaitannya dengan apa yang disampaikan guru. Justru masih terlihat anak - anak yang bermain main dengan temannya tanpa memperdulikan apa yang disampaikan oleh guru. Hasil pengerjaan siswa pada alat tes yang telah dirancang oleh guru setelah diadakan koreksi maka didapatkan hasil yang kurang memuaskan. Hasil koreksi tes awal dari 28 siswa yang ada di kelas tersebut didapatkan hasil, 5 siswa mendapatkan nilai kurang dari 60, 8 siswa mendapatkan nilai antara 60 hingga 70, sedangkan siswa yang telah tuntas atau mendapatkan nilai di atas batas ketuntasan minimal ada 15 siswa. Dari paparan hasil nilai yang didapatkan siswa maka tampak bahwa yang mencapai ketuntasan belajar hanya 53,57 \%

Setelah lembar kerja yang mengarahkan siswa untuk menemukan suatu masalah trigonometri dibagikan maka tampak siswa antusias dalam mengerjakan lembar kerja tersebut. Pada pengerjaan lembar kerja yang dibagikan ini tidak terlihat adanya siswa yang bermain - main ataupun asyik mengerjakan pekerjaan yang lain, semuanya asyik dalam mengerjakan lembar kerja yang dibagikan. Pada pelaksanaan pengerjaan lembar kerja tersebut terdapat siswa yang mengalami hambatan dalam menyelesaikan sehingga bertanya kepada teman terdekatnya, namun ada pula siswa yang mengalami hambatan dalam mengerjakan lembar kerja tersebut langsung bertanya kepada peneliti. Dalam mengerjakan lembar kerja ditemukan siswa yang belum memahami konsep dasar trigonometri yaitu tidak dapat menentukan yang mana sisi miring, sisi depan dan sisi samping. Pada post test yang diberikan setelah dikoreksi oleh guru pengajar dan peneliti didapatkan hasil sebagai berikut: Dari 28 siswa yang ada, 8 siswa mendapatkan nilai kurang dari 70, sedangkan 20 siswa telah mendapatkan nilai diatas batas tuntas, hal ini berarti 71,43\% siswa telah mampu memahami materi trigonometri. Pada pelaksanaan siklus II tampak sekali bahwa siswa sangat antusias dalam mengerjakan tugas kelompok, semua siswa terlihat aktif bersama kelompoknya 
dalam menyelesaikan lembar kerja yang diberikan peneliti. Pada saat diskusi pembahasan materi yang diberikan satu kelompok untuk ditanggapi oleh kelompok lain, kadang terlihat perbedaan pola berfikir dari masing - masing individu dalam menyampaikan ide pemecahan masalah yang diberikan. Berdasarkan evaluasi yang dilaksanakan setelah dikoreksi didapatkan hasil yang sesuai dengan indikator pencapaian hasil yang diharapkan karena dari 28 siswa yang ada dalam kelas XMIPA 1 tersebut hanya terdapat 3 siswa yang mendapatkan nilai dibawah batas ketuntasan minimal, sehingga prosentasi siswa yang telah tuntas adalah $89,29 \%$.

Hasil evaluasi yang diberikan selama 1 jam pelajaran atau 45 menit tenyata 25 siswa telah mampu mendapatkan nilai di atas batas ketuntasan minimal namun masih terlihat kesalahan yang dibuat oleh siswa dikarenakan faktor kekurang telitian siswa dalam bekerja. Masalah skill dan kecermatan dalam mengambil langkah pengerjaan masih perlu ditingkatkan agar penguaasaan materi trigionometri dapat lebih baik lagi. Keaktifan dari siswa secara keseluruhan telah sesuai yang diharapkan oleh peneliti karena dalam mengerjakan lembar kerja secara kelompok ini 99\% telah aktif dalam pembahasan lembar kerja yang diberikan. Berdasarkan hasil pelaksanaan tindakan mulai pemantauan keadaan awal hingga pelaksanaan tindakan pada siklus II maka dapat digambarkan seperti dibawah :

Tabel 1. Ketercapaian Tindakan

\begin{tabular}{clccc} 
No & \multicolumn{1}{c}{ Indikator } & \multicolumn{2}{c}{ Persentase yang dicapai } \\
1 & $\begin{array}{l}\text { Siswa dapat menyatakan } \\
\text { perbandingan trigonometri } \\
\text { pada segitiga siku - siku }\end{array}$ & $53,57 \%$ & $71,43 \%$ & $96,43 \%$ \\
2 & $\begin{array}{l}\text { Siswa dapat menggunakan } \\
\text { dalil phytagoras dan } \\
\text { perbandingan trigonometri } \\
\text { pada segitiga siku - siku } \\
\text { untuk menyelesaikan } \\
\text { masalah }\end{array}$ & & \\
& $\begin{array}{l}\text { Siswa dapat menentukan } \\
\text { perbandingan trigonomeri } \\
\text { di semua kuadran }\end{array}$ & & \\
& & & \\
\end{tabular}


Dari tabel antar siklus di atas tampak adanya hasil dari masing - masing indikator yang harus dikuasai siswa setelah diberi tindakan mengalami peningkatan yang sangat luar biasa. Dari pra siklus atau siklus awal ke siklus I pada indikator pertama mengalami peningkatan sebanyak $17,86 \%$ dan pada siklus ke II terjadi peningkatan sebesar 25\%. Hal tersebut menunjukkan bahwa peningkatan pada siklus ke II juga lebih besar daripada peningkatan pada siklus I pada kemampuan siswa dalam menyatakan perbandingan trigonometri pada segitiga siku-siku. Peningkatan yang terjadi juga tidak hanya pada indikator tersebut tetapi juga ditunjukkan pada indikator kedua yaitu kemampuan siswa dalam menggunakan dalil phytagoras dan perbandingan trigonometri pada segitiga siku-siku untuk menyelesaikan masalah. Dari tindakan yang dilakukan di siklus I menunjukkan penguasaan peserta didik pada indikator tersebut sebesar $67,85 \%$ meningkat pada siklus II menjadi 89,29\%. Hal ini menunjukkan bahwa terjadi peningkatan sebesar $21,44 \%$. Peningkatan ini tentu saja menunjukkan indikasi yang positif yang terntunya diharapkan terjadi pada penelitian tindakan kelas ini. Hasil berikutnya yang terjadi pada penelitian ini adalah siswa dapat menentukan perbandingan trigonomteri di semua kuadran. Hal tersebut ditunjukkan dengan hasil sebanyak $89,29 \%$ siswa dapat mencapai indikator tersebut.

Berdasarkan hasil penelitian yang diperoleh dapat disimpulkan bahwa strategi pembelajaran aktif dapat meningkatkan efektifitas pembelajaran trigonometri. Siswa aktif dalam pembelajaran akan dapat meningkatkan penguasaan materi trigonometri dari siswa yang bersangkutan. Pembelajaran aktif merupakan strategi yang efektif untuk menyampaikan materi trigonometri bagi siswa kelas $X$. Pembelajaran awal siswa dengan paparan hasil nilai yang didapatkan siswa maka tampak bahwa yang mencapai ketuntasan belajar hanya 53,57 \%. Pembelajaran dalam kelompok kecil dapat meningkatkan kemampuan penguasaan materi matematika dari siswa, selain itu dengan kelompok kecil ini kerjasama diantara siswa dapat tercipta dengan lebih baik. Penggunaan lembar kerja untuk membawa siswa agar aktif dalam belajar merupakan langkah yang efektif bagi siswa kelas $\mathrm{X}$ karena siswa dapat bersosialisasi dan saling tukar 
informasi serta ide atau langkah - langkah kerja untuk menyelesaikan suatu masalah dengan teman sebayanya.

\section{SIMPULAN}

Berdasarkan hasil penelitian yang diperoleh dapat disimpulkan bahwa strategi pembelajaran aktif dapat meningkatkan efektivitas pembelajaran trigonometri. Pembelajaran awal siswa dengan paparan hasil nilai yang didapatkan mencapai ketuntasan belajar hanya 53,57 \%. Setelah itu, pada pengerjaan lembar kerja ditemukan siswa yang belum memahami konsep dasar trigonometri yaitu tidak dapat menentukan yang mana sisi miring, sisi depan dan sisi samping. Pada post test yang diberikan setelah dikoreksi oleh guru pengajar dan peneliti didapatkan hasil dari 28 siswa yang ada, 8 siswa mendapatkan nilai kurang dari 70, sedangkan 20 siswa telah mendapatkan nilai diatas batas tuntas, hal ini berarti 71,43\% siswa telah mampu memahami materi trigonometri.

Evaluasi yang telah dilaksanakan setelah dikoreksi didapatkan hasil yang sesuai dengan indikator pencapaian hasil yang diharapkan karena dari 28 siswa yang ada dalam kelas $\mathrm{X}$ MIPA 1 tersebut hanya terdapat 3 siswa yang mendapatkan nilai di bawah batas kriteria ketuntasan minimal, sehingga persentase siswa yang telah tuntas adalah $89,29 \%$.

\section{DAFTAR PUSTAKA}

Gagne, R.M., \& Briggs, L.J. (1977). Principles of Instructional Design. $2^{\text {nd }} E d$. New York: Holt Rinehart and Winstons.

Hamalik, U. (2003). Kurikulum dan Pembelajaran. Jakarta: Bumi Aksara

Muijs, D. \& Reynolds, D. (2008). Effective Teaching Teori dan Aplikasi (Edisi ke-2 ) Yogyakarta: Pustaka Pelajar.

Nasution, A. H. (1982). Landasan Matematika. Jakarta : Bharata Karya Aksara.

Rusman. (2011). Model-Model Pembelajaran Mengembangkan Profesionalisme Guru. Jakarta: PT. Rajagrafindo Persada. 
Sudjana, N. (1995). Penilaian Hasil Proses Belajar Mengajar. Bandung: PT Remaja Rosdakarya.

Zaini, H. (2008). Strategi Pembelajaran aktif. Yogyakarta: Insan Mandiri.

Zaini, H., Munthe, B., \& Aryani, S.A. (2007). Strategi Pembelajaran Aktif CTSD. Yogyakarta: IAIN Sunan Kalijaga 